\title{
8 References
}

Bhushan, Indu and Kenneth Hill. 1995. The measurement and interpretation of desired fertility. Paper presented at the 1995 Annual Meeting of the Population Association of America, San Francisco, California.

Curtis, Siân and Fred Arnold. 1994. An evaluation of the reliability of the Pakistan Demographic and Health Survey based on the Pakistan Reinterview Survey. Occasional Papers, No.1. Calverton, Maryland: Macro International Inc.

Ezeh, Alex C., Michka Seroussi, and Han Raggers. 1995. Men's Fertility, Contraceptive Use, and Reproductive Preferences. DHS Comparative Studies, No. 18. Calverton, Maryland: Macro International Inc.

Lightbourne, R.E. 1985. Individual preferences and fertility behavior. In: Reproductive change in developing countries: insights from the World Fertility Survey, ed. John Cleland and John Hobcraft in collaboration with Betty Dinesen. London, England: Oxford University Press. 165-98.

Lightbourne, R.E. and Alphonse MacDonald. 1982. Family Size Preferences. WFS Comparative Studies, No. 14. Voorburg, Netherlands: International Statistical Institute.
Martin, Teresa Castro. 1995. Women's education and fertility: Results from 26 Demographic and Health Surveys. Studies in Family Planning 26(4):187-202.

Westoff, Charles F., Noreen Goldman and Lorenzo Moreno. 1990. Dominican Republic Experimental Study. Columbia, Maryland: Institute for Resource Development.

Westoff, Charles F. 1991. Reproductive Preferences. DHS Comparative Studies, No. 3. Columbia, Maryland: Institute for Resource Development.

Westoff, Charles F. 1990. Reproductive preferences and fertility rates. International Family Planning Perspectives 16(3):84-89.

Westoff, Charles F. and Akinrinola Bankole. 1995. Unmet Need: 1990-1994. Comparative Studies, No.16. Calverton, Maryland: Macro International Inc.

Westoff, Charles F., Ann K. Blanc and Laura Nyblade. 1994. Marriage and Entry into Parenthood. DHS Comparative Studies, No. 10. Calverton, Maryland: Macro International Inc. 